ORIGINAL PAPER

\title{
Features of Acute Pancreatitis Patients Admitted to a General Surgery Clinic
}

Dan Nicolae PADURARU ${ }^{1,2}$, Daniel ION ${ }^{1,2}$, Ana Maria MIHAIL ${ }^{1}$, Iuliana A. MELEANDRA ${ }^{1,2}$, Bogdan SOCEA ${ }^{1,3}$, Octavian ANDRONIC ${ }^{1,2}$, Alexandra BOLOCAN ${ }^{1,2}$

\begin{abstract}
Acute pancreatitis is an important current problem with a growing frequency and a potentially severe or even fatal evolution in some cases. In recent years, an increase in the incidence of acute pancreatitis has been observed in the population, which emphasizes the importance of establishing optimal therapeutic behavior. We performed a descriptive, retrospective clinical study, from January 2015 to November 2018, single-center, on a number of 57 patients with the diagnosis of acute pancreatitis. The presentation characteristics of patients with acute pancreatitis are largely consistent with the literature, with patient sex being the sure parameter that highlights a significant difference, with a greater number of women being diagnosed with acute pancreatitis.
\end{abstract}

Keywords: acute pancreatitis, demographics, presentation features.

\section{Rezumat}

Pancreatita acută reprezintă o problemă actuală importantă, cu o frecvență în creştere şi o evoluție severă, chiar fatală în unele cazuri. În ultimii ani s-a observat o creştere a incidenței pancreatitei acute în rândul populației, ceea ce subliniază importanța stabilirii unei abordări terapeutice optime. Am realizat un studiu clinic descriptiv, retrospectiv din ianuarie 2015 până în noiembrie 2018, într-un singur centru, pe un lot de 57 de pacienți cu diagnosticul de pancreatită acută. Parametrii pacienților cu pancreatită acută la prezentare s-au dovedit similare cu cele din literatura de specialitate, doar raportul pe sexe prezentând o diferență sigură, cu un număr mai mare de femei diagnosticate cu pancreatită acută.

Cuvinte cheie: pancreatită acută, demografie, parametri la internare.

\footnotetext{
1 "Carol Davila" University of Medicine and Pharmacy, Bucharest, Romania

${ }^{2}$ Emergency University Hospital, Bucharest, Romania

${ }^{3}$ "Sf. Pantelimon" Emergency Clinical Hospital, Bucharest, Romania
}

\section{Corresponding author.}

Bogdan Socea, "Sf. Pantelimon" Emergency Clinical Hospital, Bucharest, Romania.

E-mail: bogdansocea@gmail.com 


\section{INTRODUCTION}

Acute pancreatitis is an important current problem with a growing frequency and a potentially severe or even fatal evolution in some cases. In recent years, an increase in the incidence of acute pancreatitis has been observed in the population, which emphasizes the importance of establishing optimal therapeutic behavior ${ }^{1}$.

Patients with severe acute pancreatitis often have considerable systemic inflammatory response and different grades of organ failure. These patients are exposed to the risk of developing local complications, such as pancreatic necrosis, pseudo-aneurysms and bleeding, fistulae and strictures, or infection of the pancreatic necrosis $^{2}$.

The present study aims to analyze the characteristics of patients with acute pancreatitis admitted to a general surgery clinic in Romania.

\section{MATERIALS AND METHODS}

We performed a descriptive, retrospective clinical study, from January 2015 to November 2018, single-center, in the General Emergency Surgery Clinic III of the University Emergency Hospital Bucharest, on a number of 57 patients with the diagnosis of acute pancreatitis.

\section{Inclusion criteria:}

1. Patients over 18 years old;

2. Patients diagnosed clinically (according to the criteria), paraclinical and imagistic with acute pancreatitis.

\section{Exclusion criteria:}

The criteria for exclusion of patients from the study were:

1. Patients diagnosed and treated in the outpatient setting for acute pancreatitis;

2. Patients diagnosed with a history of acute pancreatitis, whose episode has resolved and is currently being treated for late complications of the pathology.

\section{RESULTS}

Of the 57 patients diagnosed with acute pancreatitis, 34 were female and 23 were male. The age of the patients was between 20 and 83 years, with an average value of 51.25 years.

Of all 57 patients diagnosed with acute pancreatitis, most of them, i.e. 42, were subsequently diagnosed with pancreatitis due to billiary etiology. A less visible numbers of pancreatitis were due to the other etiologies: hypertriglyceridemia (6 patients), alcoholic (5 patients) and idiopathic (4 patients).

The most common risk factor was dyslipidemia, present in $47 \%$ of cases, followed by the interventional and therapeutic procedure known as retrograde endoscopic cholangiopancreatography, which was performed in $38 \%$ of cases. Alcohol and obesity were present in a similar number of cases, both being present in $22 \%$ of cases (separately or together), and lithiasis was found in $15 \%$ of cases. In patient's history, surgery performed recently was found in $8 \%$ of cases, and hypercalcemia and pregnancy were present in only $3.5 \%$ of cases.

Of all 57 patients diagnosed with acute pancreatitis, a majority of 32 had elevated amylazemia levels more than 3 times the normal value, which represents $56 \%$. $32 \%$ of patients had normal amylase values, and $12 \%$ had elevated values, but below the diagnostic limit. The mean value of amylase among patients was $1022 \mathrm{U} / \mathrm{L}$, with a median of $509 \mathrm{U} / \mathrm{L}$ and a standard deviation of 1177 U / L (Table 1).

Compared with patients with elevated amylase values, those with values more than 3 times the normal value of lipase are found in a higher percentage, respectively $65 \%$. 28\% had normal lipase values, and $7 \%$ of patients had elevated lipase values, but below the diagnostic limit. The average serum lipase values were $4213 \mathrm{U} / \mathrm{L}$, the median of $3713 \mathrm{U} / \mathrm{L}$, and the standard deviation of $3886 \mathrm{U} / \mathrm{L}$.

Blood glucose levels were increased at 37 patients, representing a majority of $65 \% .35 \%$ had normal blood glucose levels at admission. This may be explained by decreased insulin release in acute pancreatitis or because of increased release of hyperglycemic hormones in acute stroke.

$67 \%$ of patients presented with normal triglyceride values, $23 \%$ with normal-raised values and only $10 \%$ of them had significantly increased values. The mean serum triglyceride values were around $130 \mathrm{mg} / \mathrm{dL}$, with a median of $120 \mathrm{mg} / \mathrm{dL}$ and a standard deviation of $56 \mathrm{mg} / \mathrm{dL}$. Although a large proportion of patients presented as the main risk factor dyslipidemia, this was probably due to other changes in the lipid formula and not to hypertriglyceridemia. At the same time, many of these patients may already be on medication to reduce serum triglyceride levels.

Most patients, representing $72 \%$, had a normal serum bilirubin value, while the remaining $28 \%$ had an increased bilirubin. This percentage is slightly higher 
Features of Acute Pancreatitis Patients Admitted to a General Surgery Clinic

Table 1. Distribution of patients in relation with biological parameter values

\begin{tabular}{|c|c|c|c|c|c|}
\hline & Mean & SD & Median & Minimum & Maximum \\
\hline Hemoglobin & 12.41 & 4.127 & 11.9 & 5.2 & 16.1 \\
\hline Leukocytes & 11129,84 & 4234,987 & 9800 & 1200 & 21300 \\
\hline Glucose & 129,07 & 49,886 & 120 & 74 & 340 \\
\hline Lipase & 4213,56 & 3886,261 & 3713 & 13 & 13899 \\
\hline Amylase & 1022,57 & 1177,706 & 509 & 14 & 5137 \\
\hline ALT (SGPT) & 175,17 & 224,144 & 83 & 11 & 1144 \\
\hline AST (SGOT) & 126,40 & 135,708 & 67 & 15 & 640 \\
\hline Triglycerides & 129,75 & 55,980 & 120 & 37 & 269 \\
\hline Cholesterol & 165 & 59,065 & 167 & 68 & 290 \\
\hline $\mathrm{LDH}$ & 314,08 & 470,453 & 238 & 130 & 3749 \\
\hline Direct bilirubin & 0,84 & 1,426 & 0,300 & 0,1 & 8,80 \\
\hline Total bilirubin & 1,539 & 1,888 & 0,850 & 0,30 & 10,50 \\
\hline Urea & 29,87 & 11,339 & 29 & 10 & 67 \\
\hline Creatinine & 0,88 & 0,249 & 0,840 & 0,30 & 1,40 \\
\hline Fibrinogen & 470,43 & 136,621 & 440 & 247 & 918 \\
\hline K & 3,984 & 0,545 & 4,200 & 3,10 & 4,90 \\
\hline $\mathrm{Ca}$ & 8,800 & 0,871 & 8,800 & 6,90 & 10,80 \\
\hline $\mathrm{Na}$ & 138,526 & 4,049 & 139 & 120 & 145 \\
\hline
\end{tabular}

than expected (10\%) from previous studies, but it does not make a difference. Of these, $25 \%$ had increased direct bilirubin, and the remaining $3 \%$ implicitly the indirect one.

The value of serum LDH was normal in 29 patients out of 47 , representing $51 \%$ of the total. Slightly higher values were observed in $35 \%$ of cases, and values over $350 \mathrm{mg} / \mathrm{dL}$ were reported in $14 \%$ of cases. These percentages could inform us about the percentage of patients who would fall into an increased risk category, with values above $350 \mathrm{mg} / \mathrm{dL}$ being a strong predictor of persistent organ failure. The mean LDH was $314 \mathrm{mg}$ / dL, with a median of $238 \mathrm{mg} / \mathrm{dL}$ and a standard deviation of $470 \mathrm{mg} / \mathrm{dL}$.

The highest percentage of patients, ie $72 \%$, presented with normal values of serum calcium upon admission. $3 \%$ of them had high levels of calcium, and 25\% had low values, this being explained by the process of fixing calcium at the level of cytosteatonecrosis stains and representing a predictor of severity of pancreatitis

The hemoglobin value was found to be normal in 36 patients out of 57 , with the remaining 21 showing low values. $63 \%$ had normal hemoglobin values and only $37 \%$ had low hemoglobin. The value of hemoglobin is important given the fact that it may decrease dramatically in the case of severe hemorrhagic pancreatitis.

Out of the total number of 57 patients included in the study, 33 were presented with normal leukocyte values, 21 with increased values, but not over 20.000 / $\mathrm{mmc}$, and only 3 patients had leukocyte numbers over $20,000 / \mathrm{mmc}$. The mean value was 11.130 leukocytes / mmc, the median was 9.800 leukocytes / $\mathrm{mmc}$, and the standard deviation was 4.235 leucocytes / mmc. As a percentage, $58 \%$ of patients had normal values, $37 \%$ had high values and only $3 \%$ of them had a very large increase in leukocytes. Considering that at the onset of pancreatitis, high levels of leukocytes and inflammatory syndrome can be recorded without the presence of an infection, these data could provide information about the very small percentage of patients who could actually present an infection at the local inflammatory process.

The presence of increased fibrinogen was reported in 41 of 57 patients, the remaining 16 presenting with normal values. The increase of fibrinogen suggests the existence of an inflammatory syndrome, present in only $28 \%$ of cases. $72 \%$ of patients presented with normal fibrinogen values. At the same time, the growth of fibrinogen and leukocytes should not point to the suspicion of an infectious process, especially at the onset of acute pancreatitis, these increases being expected during this pathology.

Usually, the clinical, biochemical and imaging aspects facilitate a quick and easy diagnosis in the case of acute pancreatitis, especially when it comes to the mild ones and without the high risk of complications. In moderately-severe cases or when the presence of infection, fluid collections and other complications is 
Table 2. Distribution of patients according to severity using Balthazar computed tomography score

\begin{tabular}{|l|c|c|c|c|c|}
\hline & \multicolumn{5}{|c|}{ Balthazar score } \\
\cline { 2 - 6 } & A & B & C & D & E \\
\hline Number of patients & 5 & 8 & 9 & 4 & 11 \\
\hline
\end{tabular}

suspected, it is recommended to perform a computed tomography or magnetic resonance imaging. For the patients included in the study, a computed tomography was performed in a number of 37 patients, representing $65 \%$ of the total number. The remaining $35 \%$ of patients did not require this investigation.

Of the total number of 37 patients who underwent CT imaging, 5 were classified as Balthazar severity score $\mathrm{A}, 8$ as $\mathrm{B}$ score, 8 as $\mathrm{C}$ score, 4 as $\mathrm{D}$ score, and as 11 as $\mathrm{E}$ (Table 2).

Balthazar score brings us information on the severity of the episode of pancreatitis and can be used to formulate the prognosis of patients regarding complications and mortality. However, this score is by far not the most accurate score that can be used in severity grading, which will be confirmed later, with the description of the proportions of the types of acute pancreatitis found in the patients in the study and their good outcome.

43 patients were diagnosed with edematous pancreatitis, representing $75 \%$ of the total. Necrotic pancreatitis was present in 12 cases, and hemorrhagic in only 2 cases (Table 3 ). The evolution of edema-like pancreatitis is milder and less affected by the occurrence of complications.

In terms of severity, of the total 57 patients, 46 were diagnosed with mild pancreatitis, 8 with moderate pancreatitis and the remaining 3 patients with severe pancreatitis. As a percentage, $81 \%$ of the cases were

Table 3. Distribution of patients according to the histological type of pancreatitis

\begin{tabular}{|l|c|c|c|}
\hline \multirow{2}{*}{} & \multicolumn{3}{|c|}{ Pancreatitis type } \\
\cline { 2 - 4 } & Edematous & Necrotic & Hemorrhagic \\
\hline Number of patients & 43 & 12 & 2 \\
\hline
\end{tabular}

Table 4. Distribution of patients according to the severity of the episode of pancreatitis

\begin{tabular}{|l|c|c|c|}
\hline \multirow{2}{*}{} & \multicolumn{3}{|c|}{ Severity } \\
\cline { 2 - 4 } & Mild & Moderate & Severe \\
\hline Number of patients & 46 & 8 & 3 \\
\hline
\end{tabular}

mild pancreatitis, $14 \%$ moderate pancreatitis and 5\% severe pancreatitis (Table 4).

The most common complication during the evolution of acute pancreatitis among the patients included in the study was pleuritis, present in a percentage of $21.05 \%$. The next complication by the frequency is represented by the systemic inflammatory response syndrome, present in a percentage of $19.20 \%$. In almost equal proportions, of $8.77 \%$ and $7 \%$ were found pneumonia, respectively the pseudo-cyst, and the peritonitis was present in a percentage of $5.26 \%$. In the proportion of $3.5 \%$, the occurrence of diabetes, sepsis and / or multiple organ failure was reported. The rarest complication, occurring in $1.75 \%$ of cases, is fistula (Table 5).

Most patients, totaling 48, fall within the limits of 0-2 of the BISAP score, and the remaining 9 patients fall into the BISAP scores 3-5. As a percentage, $84.21 \%$ of cases belong to scores 0-2 BISAP and $15.79 \%$ to scores 3-5 BISAP. This prognostic score provides information on the risk of mortality from acute pancreatitis, which in this case is below $2 \%$ for the vast majority of patients (those in grades 0-2) and over 15\% for the rest of patients (those in scores 3-5).

\section{DISCUSSIONS}

Demographic data, on which there are still inconsistencies in the literature, showed a higher incidence of acute pancreatitis among women. This contradicts the information known to date, which places male sex as the first place of incidence ${ }^{1}$.

\begin{tabular}{|c|c|c|}
\hline & & Number of patients \\
\hline \multirow{9}{*}{ Complications } & Pleuritis & 12 \\
\hline & SIRS & 11 \\
\hline & Pneumonia & 5 \\
\hline & Pancreatic pseudocyst & 4 \\
\hline & Peritonitis & 3 \\
\hline & Diabetes Mellitus & 2 \\
\hline & Sepsis & 2 \\
\hline & MSOF & 2 \\
\hline & Fistula & 1 \\
\hline
\end{tabular}


Regarding the age with the highest susceptibility to acute pancreatitis, according to the data recently found, it varies according to the main etiology of the disease. However, the study has shown a high incidence in people over 40 years, regardless of etiology, but this peak tends to decrease dramatically after age 80 , most likely due to reduced survival after this age ${ }^{2}$.

Regarding the etiology of acute pancreatic disease, the data currently known bring us information regarding the frequency of etiologies in populations according to the gender and age of the patients, not having reached a consensus regarding the superiority of an etiology in the general population. Regarding the etiology of the cases of acute pancreatitis among the patients included in the study by gender, the study data correspond to those currently recognized which attribute to the female sex a higher frequency of the biliary etiology and the male sex of the alcohol etiology. A difference was observed, however, with the attempt to compare etiologies by age category. Although alcoholic etiology was known to be the main cause in the 40-60 age group, bile etiology was also in the first place $^{3-6}$.

Consistent with the frequency of etiologies of acute pancreatitis episodes developed by the patients in the

\section{References}

1. Johnson CD, Besselink MG, Carter R. Acute pancreatitis. BMJ. 2014 Aug 12;349:g4859. doi: 10.1136/bmj.g4859. Review. PubMed PMID: 25116169.

2. Habtezion A. Inflammation in acute and chronic pancreatitis. Curr Opin Gastroenterol. 2015 Sep;31(5):395-9. doi: 10.1097/ MOG.0000000000000195.

3. Working Group IAP/APA Acute Pancreatitis Guidelines. IAP/APA evidence-based guidelines for the management of acute pancreatitis. Pancreatology. 2013 Jul-Aug;13(4 Suppl 2):e1-15. doi: 10.1016/j.pan.2013.07.063.

4. Bollen TL. Acute pancreatitis: international classification and nomenclature. Clin Radiol. 2016 Feb;71(2):121-33. doi: 10.1016 /j.crad.2015.09.013. Epub 2015 Nov 19. Review. PubMed PMID: 26602933.

5. Minkov GA, Halacheva KS, Yovtchev YP, Gulubova MV. Pathophysiological mechanisms of acute pancreatitis define inflammatory markers of clinical prognosis. Pancreas. $2015 \mathrm{Jul}$; 44(5):713-7. doi: 10.1097/MPA.0000000000000329. study, hypertriglyceridemia was ranked first in frequency (obviously contributing to billiary pathology), being present in $47.3 \%$ of cases. Although alcohol consumption is not in the second place, it is occupied by the ERCP (also in accordance with the frequency of the billiary etiology), it ranks third among the risk factors, being present in a percentage of $22.8 \%$, equal to that of obesity $^{7-10}$.

\section{CONCLUSIONS}

The presentation characteristics of patients with acute pancreatitis are largely consistent with the literature, with patient sex being the sure parameter that highlights a significant difference, with a greater number of women being diagnosed with acute pancreatitis.

Compliance with ethics requirements: The authors declare no conflict of interest regarding this article. The authors declare that all the procedures and experiments of this study respect the ethical standards in the Helsinki Declaration of 1975, as revised in 2008(5), as well as the national law. Informed consent was obtained from all the patients included in the study.

6. Bolado F, de-Madaria E. Novel findings in the management of acute pancreatitis. Gastroenterol Hepatol. 2016 Sep;39 Suppl 1:102-108. doi: 10.1016/S0210-5705(16)30181-9.

7. Ribeiro A, Goel A. The Risk Factors for Acute Pancreatitis after Endoscopic Ultrasound Guided Biopsy. Korean J Gastroenterol. 2018 Sep 25;72(3):135-140. doi: 10.4166/kjg.2018.72.3.135.

8. Rashidi M, Røkke O. Prospective evaluation of the cause of acute pancreatitis, with special attention to medicines. World J Gastroenterol. 2016 Feb 14;22(6):2104-10. doi: 10.3748/wjg. v22.i6.2104.

9. Hagjer S, Kumar N. Evaluation of the BISAP scoring system in prognostication of acute pancreatitis - A prospective observational study. Int J Surg. 2018 Jun;54(Pt A):76-81. doi: 10.1016/j. ijsu.2018.04.026

10. Rehan A, Shabbir Z, Shaukat A, Riaz O. Diagnostic Accuracy of Modified CT Severity Index in Assessing Severity of Acute Pancreatitis. J Coll Physicians Surg Pak. 2016 Dec;26(12):967-970. 
